\title{
THE ROLE OF UNIVERSITY CROWN FOUNDATIONS IN HIGHER EDUCATION POLICY: A CROSS-CANADA STUDY [1984-1998]
}

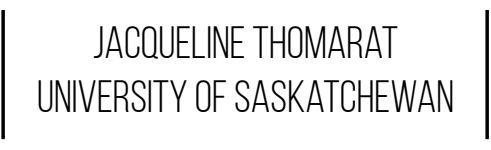

\begin{abstract}
This qualitative case investigation considers the historical, inter-provincial proliferation of university Crown foundations across Canada from 1984 to 1998. From the findings of over 40 interviews conducted between 2014 and 2017 and document analysis, this study uses a conceptual framework of policy entrepreneurship and institutionalism to provide evidence of Crown foundations' policy engagement in post-secondary education and fiscal policy in Canada. The efforts to increase the availability of tax incentives to the system by policy entrepreneurs increased resources available to Canadian university Crown foundations, although the advantage to universities was only temporary.

Keywords: Crown foundations, policy, entrepreneur, higher education

\section{Résumé}

Cette enquête qualitative considère l'expansion du nombre de fondations universitaires publiques au Canada de 1984 à 1998 . Les résultats de plus de 40 entrevues conduites entre 2014 et 2017 et l'analyse de documents informent cette étude, qui utilise comme cadre conceptuel l'entrepreneuriat politique et l'institutionnalisme pour faire la preuve de l'engagement des fondations publiques dans les politiques relatives à l'enseignement postsecondaire et les politiques fiscales au Canada. Les efforts visant à accroître la disponibilité des incitatifs fiscaux par les entrepreneurs en politiques ont augmenté les ressources à la disposition des fondations universitaires publiques canadiennes, mais l'avantage fut seulement temporaire pour les universités.
\end{abstract}

Mots-clés : Fondations de la Couronne, politiques, entrepreneur, enseignement supérieur

\section{Introduction}

Charitable foundations, including Crown foundations, use private tax-exempt resources to advocate for and even direct government priorities and policies. The legitimacy of Crown foundations' policy interests has been contested because they do not necessarily represent those of the electorate (Prewitt, Dogan, Heydemann, \& Toepler, 2006). Is it appropriate and legitimate for policy entrepreneurs (Kingdon, 1995) to proliferate the Crown foundations by exploiting tax exemptions available only to the Crown? This qualitative case study examines and explains policy entrepreneurs' use of Crown foundations to increase the funding available to provincial universities across Canada from 1984 to 1998 . This study finds that the end result of the federal government's fiscal policy prerogatives for provincial post-secondary education
(PSE) is that tax advantages such as these can only be short lived.

The advantage of Crown foundations at the time under investigation was that under the Canadian Income Tax Act (1985) donations to the Crown could be credited in a given year up to $100 \%$ of the donor's annual income (Neely, 1995, p. 32). Up until 1996/97, donations toward all other charities including public and private foundations were only eligible for tax credits up to $20 \%$ of the donor's annual income. Universities and hospitals, as agents of the Crown, were allowed to establish parallel Crown foundations. Donations to the Crown substantially reduced the tax burden paid by the donor in a given year. This tax break would have been advantageous to donors particularly in years when an individual's income was exceptionally high (Bowman, 1996). This rule ap- 
plied to the year of death and the prior year, making it an attractive planned giving incentive to be carried out via bequests. The Crown foundation tax incentive was targeted at wealthier donors and was meant to encourage larger gifts (Bromley, 1993).

It is important to make a clear distinction between Crown foundations and parallel foundations. Both parallel foundations and Crown foundations are public foundations. A Crown foundation is an agent of the Crown, usually created through an act of a provincial government (Neely, 1995). Crown foundations are parallel foundations, but parallel foundations are not usually Crown foundations. A parallel foundation "is a foundation set up by an operating charity to raise funds and hold investments primarily for that operating charity" (Bromley, 1993, p. 37). A parallel foundation distributes funds only to its charitable organization. For example, in their current form, hospital foundations are commonly parallel foundations. Parallel foundations, both in the past and today, have enjoyed similar tax benefits as other public foundations (excluding Crown foundations).

The first university Crown foundation in Canada was established in British Columbia (BC) in 1987, with assurances from the federal government that these newly established PSE Crowns would benefit from the same tax incentives as the Crown. Thereafter, university Crown foundations were established across the provinces: in Alberta in 1991, Ontario in 1992, in Manitoba, Nova Scotia and New Brunswick in 1993, Saskatchewan in 1994, and in Québec in 1996. After the tax incentives for Crown foundations and other types of foundations and charities were changed to being equivalent in 1996/97, in 1997/98 two new federal Crown foundations in the PSE sector were established. These federal PSE Crown foundations were the Canadian Foundation for Innovation (CFI) and the Millennium Scholarship Foundation. As will be discussed, their creation had the effect of moving policy influence back to the federal government and away from university foundation policy entrepreneurs (Kingdon, 1995), but also away from the provinces who had made the effort to establish the provincial Crowns through acts of their respective legislatures.

In order to study Crown foundations, the research method used is a qualitative case study that builds on the findings of over 40 interviews conducted from 2014 2017 and of document analysis. The research questions are: who are foundations as policy actors in PSE? What resources do they have at their disposal to affect PSE public policy making? At what stage are they influential in the policy cycle? Why do these policy entrepreneurs participate in PSE policy? The conceptual framework for this study uses elements of policy entrepreneurship (Howlett 1997, 1998; Kingdon, 1995; Lindquist 1989, 2006) and institutionalism (Hall \& Quinn, 1983; Lecours 2005; Powell and DiMaggio 1991). US, UK, and Canadian research on foundations and think tanks often describes them as policy entrepreneurs who are engaged at the agenda-setting stage of the policy cycle (Abelson 2005; Fleishman 2007; Kendall 2000; Prewitt, 2006; Stone 1997). Institutional perspectives underscore the importance of legislative frameworks for foundations in Canada.

This research on Crown foundations in Canada is important because PSE public policy is affected by power, which foundations wield while representing particular interests; and both policies that foundations pursue and the ones by which they are regulated can make a difference for the public good. This investigation informs researchers; grantees (charitable and non-profit organizations [NPO]); policy makers; elected officials; and foundation staff, boards, and executives about foundations' growing involvement in public policy. By employing the policy-cycle approach and institutional perspectives, the research will address some of the limitations of the multiple streams framework (MSF) which would otherwise overshadow the usefulness of the concept of policy entrepreneur for these purposes (Kingdon, 1995).

\section{Literature Review}

The literature is largely silent on Crown foundations in Canada with the exceptions of Aucoin (2003), Bromley (1993), Minton and Somers (2016), and Neely (1995). Publicly available data on foundations indicates that there are at least 86,000 registered charities in Canada, and over 10,000 foundations (Blumberg \& Sawyer, 2018; Philanthropic Foundations Canada, 2017). About half of these foundations are public, and half are private. Foundations are in fact the fastest growing type of charity in Canada (Blumberg \& Sawyer, 2018; Imagine Canada and Philanthropic Foundations Canada, 2014; Philanthropic Foundations Canada, 2017). PFC reports that in 2015 , foundations managed approximately $\$ 71$ billion in assets, and made over $\$ 5.6$ billion in grants. Of this sum, public foundations made $\$ 3.6$ billion in grants, and private foundations $\$ 2$ billion (Imagine Canada and Philanthropic Foundations Canada, 2014). Yet, amongst the members 
of PFC that were primarily private family foundations, about two thirds of grants were made to "foundation-managed" charitable causes. This could be interpreted as evidence of the primarily donor-directed nature of private foundation funding (Philanthropic Foundations Canada, 2017) that has historically garnered critique.

In terms of the distribution of assets among foundations, 150 of the top grant-making ${ }^{1}$ foundations in Canada contributed over $25 \%$ of total grants made by foundations, which represented approximately $\$ 1$ billion in gifts. The MasterCard Foundation, the largest foundation in Canada, gave the most at $\$ 84.1$ million. In $2014,30 \%$ was distributed to education, $17 \%$ to health, followed by social services at $10 \%$. The remainder included, for example, international causes, voluntarism, fundraising, environment, and housing. Only $1 \%$ (or $\$ 9.1$ million) was directed at legal, political, or advocacy (see Glossary) causes; only $8 \%$ ( $\$ 77.6$ million) went toward religious causes (Imagine Canada and Philanthropic Foundations Canada, 2014).

Foundations' granting practices contribute to the disparities in organizations' size and scope in the Canadian third sector in the context of declining public funding and increasing costs of social services like higher education and healthcare. Geographically, information from T3010 tax forms and data self-reported to Imagine Canada's Grant Connect database shows that, of the annual donations for the 150 largest foundations in Canada (which control over $\$ 18$ billion in assets), about half are distributed in Ontario, a fifth in Québec, and only a twelfth across Manitoba, Saskatchewan, and the Maritimes combined (Imagine Canada and Philanthropic Foundations Canada, 2014).

The Canada Revenue Agency (CRA) defines a foundation as "a registered charity that makes grants to other charities and to those organizations recognized by the federal government as "qualified donees"' (Canada Revenue Agency, 2016, p. 1). The Income Tax Act (1985) establishes the legislative framework for charities and foundations, provides foundations with an operational mandate and, more generally, sets the basis for the relationship between the government and the third sector. The Income Tax Act (1985) is also a source of challenges for the third sector (Bromley, 1999; Burrows, 2009; Hoffstein 2007; Payne \& Zhao, 2007; Phillips, Chapman, \& Stevens 2001; Phillips, 2007; Sexty, 1980; Sharpe, 1994). The contentious issue is whether the CRA should assist and enable the sector to achieve their policy goals or whether the CRA's primary function is to enforce appro- priate regulation, accountability, and oversight. In terms of institutional context, foundations' policy roles are contested because they have limited representational scope. Lack of coherent policy objectives has constrained their policy influence (Pearson, 2010; Phillips \& Rathgeb Smith, 2011; Reckhow, 2016).

Some argue that foundations' roles in policy making are akin to-or limited to-their roles as funders (Lenkowsky, 2002). Foundations also play an intermediary function between individual donors and recipients, which serves to reduce information asymmetries and inefficiencies that arise from crowding out of a growing number of potential recipients (Kyrvoruchko, 2013). Neither of these are benign or apolitical functions. In a collection of articles on the politics of foundations in the United States, Teles (2016) argues that the character of funding sources, including the organizational form particular to foundations, and their political preferences determine the allocation of resources and foundations' strategic choices.

The nature of foundations' policy roles is inherently political. In a comparative study, Anheier and Daly (2007) note the impact that different national and jurisdictional contexts have. Reich (2016) suggests that private foundations represent the legal institutionalization and acquisition of private wealth in the place of public funds for public purposes. Research on foundations shows that, as foundations grow in number and as their assets increase, they become increasingly politicized and institutionalized, although their roles tend to be somewhat contentious (Abelson, 2016; Anheier \& Daly, 2006; Elson, 2011; Phillips, 2007; Stone, Denham \& Garnett, 1998). Their legitimacy is contested depending not only on the issue but also on the jurisdiction (Anheier \& Daly, 2007; Prewitt, 2006).

\section{Methods}

A descriptive, qualitative research study is presented here. This case considers the role of Crown foundations in post-secondary education in the 1980s and 1990s. This was a little-known case with potentially far-reaching impacts. Given the national scope and the potential to examine the roles of foundations across the provinces, this case on Crown foundations considers a unique organizational type when it comes to foundations (as compared to the more commonly researched private, public and parallel foundations), and therefore an area for future research that compares foundations cross-nationally. Semi-structured interviews with 41 policy actors and 
experts were conducted over the course of a 36-month period. This was complemented by extensive reviews of primary-source documentation, archival materials, and secondary research. The research design and analysis involved explanation building, constructing a thick-descriptive chronological narrative, discovering and recording the findings, and building the theoretical contribution through an iterative analytical process.

\section{The Policy Agenda}

Up until the 1997 income tax policy changes for the Crown, Crown foundations had more tax advantages than all other types of charitable organizations (Canada Revenue Agency, 1997). $100 \%$ of donations to foundations were eligible for tax credit, but only up to a threshold of $20 \%$ of the donor's annual income. Whatever tax benefits exceed those amounts may be carried forward for up to five years. Historically, the same tax benefits applied whether a donor gave to a charitable organization, a public foundation, or a private foundation. The Income Tax Act (1985) contained an overlooked clause that created a potentially significant advantage to donating to an "Agent of the Crown," as opposed to another form of charity (Bromley, 1993). There was no annual limit on tax credits to the Crown, or thereby Crown foundations, and they still had carry-forward privileges.

In 1984, Blake Bromley, president of Benefic Group and a professional in charity law, noted this tax incentive for agents of the Crown. Bromley had been working to steward a potential gift from a major donor to the University of British Columbia (UBC) when he uncovered that donations to Crowns offered better tax incentives than did registered charities (Bromley, 1993; Interview no. 16, 2015, November 17). The finding was of considerable importance to the donor, who was interested in donating to PSE (Interview no. 16, 2015, November 17). The tax incentive that was unique to Crown agencies, which by extension, universities and hospitals might also qualify for. Bromley requested that the premier of British Columbia "pass legislation to create a Province of British Columbia
Endowment Agency" (the precursor to the Crown foundation formulation of the policy) for universities and hospitals in the province (Bromley, 1993, p. 8). The first request to the province was submitted in 1984. The "agent of the Crown" was not established until 1987 (Neely, 1995).

\section{Policy Entrepreneurship: Inter- Provincial Policy Transfer}

The creation of university Crown foundations swept the country following the establishment of the UBC Crown foundation in $1987 .{ }^{2}$ The policy transfer was spurred by the informal, personal connections between the growing cadres of tax experts for charitable giving, and planned giving professionals at universities and other third-sector organizations, especially hospitals (where there were also Crown foundations).

At the time the professional fundraising sector in Canada was beginning to grow. It was a close-knit group of people who often shared success stories, lessons learned, and other opportunities. This group eventually became a regional members' association of the Canadian Association of Gift Planners (CAGP). According to the interviews conducted for this case, the conversations between members of this policy network at the time focused on understanding and advocating for better tax incentives for giving. They were of a different nature than the conversations in the professional community today, where the focus is more broadly on understanding motivations for giving, not just tax incentives (Interview no. 35, 2016, Aug. 19; Interview no. 41, 2017, April 17). Through this policy network, and spurred by the Crown foundations, knowledge about the Crown foundation opportunity for universities spread across the provinces.

A Council for the Advancement and Support of Education (CASE) three-day planned giving seminar was held in Banff in March 1990 to discuss the idea of establishing Crown foundations. As outlined in table 1, the establishment of university Crowns across the provinces took off shortly thereafter.

Table 1. Establishment of university Crown foundations across Canada

\begin{tabular}{|l|l|l|}
\hline Province & Year & University Crown Foundation Structure \\
\hline $\begin{array}{l}\text { British Columbia } \\
\text { (BC) }\end{array}$ & 1987 & $\begin{array}{l}\text { University Foundations Act (BC 1987) - umbrella legislation allowed for Crown foundations } \\
\text { for each university }\end{array}$ \\
\hline
\end{tabular}




\begin{tabular}{|l|l|l|}
\hline Province & Year & University Crown Foundation Structure \\
\hline Alberta (AB) & 1991 & $\begin{array}{l}\text { Universities Foundations Act (AB 1991) - umbrella, allowed for Crown foundations for each } \\
\text { university }\end{array}$ \\
\hline $\begin{array}{l}\text { Saskatchewan } \\
\text { (SK) }\end{array}$ & 1994 & $\begin{array}{l}\text { Crown Foundations Act (SK 1994) - established a foundation for each U of S and the Uni- } \\
\text { versity of Regina }\end{array}$ \\
\hline Manitoba (MB) & 1993 & $\begin{array}{l}\text { The Manitoba Foundation Act (MB 1993) - umbrella for any university or college estab- } \\
\text { lished under MB legislation; also included hospitals and cultural organizations }\end{array}$ \\
\hline Ontario (ON) & 1992 & $\begin{array}{l}\text { University Foundations Act, 1992 (ON 1992) - created Crown foundations for each ON } \\
\text { university }\end{array}$ \\
\hline Québec (QC) & 1996 & An Act Respecting University Foundations (QB 1996) - umbrella \\
\hline Nova Scotia (NS) & 1993 & $\begin{array}{l}\text { University Foundations Act (NS 1993) - umbrella, allowed for Crowns for each of NS's 13 } \\
\text { universities }\end{array}$ \\
\hline $\begin{array}{l}\text { New Brunswick } \\
\text { (NB) }\end{array}$ & 1992 & $\begin{array}{l}\text { Higher Education Foundation Act (NB 1992) - allowed for the establishment of Crowns for } \\
\text { each university, college, and education institution }\end{array}$ \\
\hline PEI & NA & No legislation. \\
\hline $\begin{array}{l}\text { Newfoundland } \\
\text { (NF) }\end{array}$ & 1996 & $\begin{array}{l}\text { Memorial University Foundation Act (NF 1996) - Crown foundation for Memorial University } \\
\text { of Newfoundland. }\end{array}$ \\
\hline
\end{tabular}

Sources: Neely 1995; Bromley 1993, 12; Sask. 1994; Minton and Somers 2016; Table 1 summarizes Neely's findings and updates the data using data retrieved from the provincial governments' legislation.

In each province, the nature of the legislation varied with respect to the structures of the governing boards, and how autonomous Crown foundations were vis-à-vis their provincial governments and the universities. Nevertheless, the purposes of the university foundations (like hospital foundations) in all the provinces were similar: "to solicit, receive, manage and distribute money and other property" in support of the education, research, and outreach missions of the organizations (Neely, 1995, p. 30). This is evidence of the growth of Crown foundations.

The Banff Centre conference was sponsored by the Canadian Association of Educational Development Officers (now the Canadian Council for the Advancement of Education) and was attended by chief development officers and directors of planned giving from across the country (Interview no. 41, 2017, April 17; Minton \& Somers, 2016, 5). Planned giving was then a burgeoning professional field. It has grown from ten or so members in 1992 to approximately 1,300 members today. The conference was an opportunity to promote the Crown foundations policy, and it also offered a chance for collaboration (Minton \& Somers, 2016).

By 1992/93, this country-wide network of gift planners (i.e., fundraising professionals, estate and trust lawyers, bankers, trust officers, accountants, investment advisors, and sector advocates) began working together. As a result of these developments, the next case of net- work building in the sector was the creation of the Canadian Association of Gift Planners in 1992. In 1994, Minton and Somers noted:

In 1993, the newly formed Canadian Association of Gift Planners encouraged Lorna Somers and me to produce a basic reference to serve the growing number of individuals and charities interested in planned giving. The result was the first edition of Planned Giving for Canadians, published in 1994. (2016, xix)

The formalization of the planned giving policy network through the creation of new umbrella organizations in Canada occurred under the auspices of the CAGP (Bromley, 1993; Interview no. 38, 2016, September 9; Interview no. 41, 2017, April 17). This group continues to lead conversations regarding tax legislation for major and planned giving (Minton \& Somers, 2016). The CAGP held its first annual conference in 1994. It was the first Canadian umbrella fundraising organization to include professions other than fundraisers (e.g., lawyers, financial advisors, estate planners, accountants) and included accountants or tax lawyers, even those from the private sector, which speaks to the development of the policy network. The Association of Fundraising Professionals (AFP), by way of contrast, is only for fundraisers. The 
nexus of these growing policy networks was the Crown foundation policy agenda, in addition to other common interests and learning opportunities (Interview no. 41, 2017, April 19).

Alongside the establishment of Crown foundations for universities, between 1990 and 1994, the policy entrepreneurs in the small policy networks realized that there were potential advantages of being more organized. The small network of individuals who were participants in this Crown foundation policy agenda eventually formed a chapter of the CAGP (Interview no. 41, 2017, April 17). A Canadian arm of the Council for the Advancement of Education (CAE) was also established (Interview no. 35, 2017, August 19; Minton \& Somers, 2016). These umbrella organizations enabled the policy transfer of the Crown foundation tax incentive across the provinces.

Bromley published an article sharing information about the potential of Crown foundations for fundraising in 1993. Neely, then a practising professional fundraiser at the Vancouver Hospital Foundation, wrote an article about this Canadian policy trend in 1992, which she presented to the CAGP in 1993 and published in Philanthropist in 1995. Neely documented this pan-Canadian trend of establishing Crown foundations. In 1994, Somers and Minton published the first edition of Planned Giving for Canadians.

\section{Policy Evaluation}

In the 1997 federal budget, the Liberal government changed the tax structures for Crown foundations, thereby removing the advantage that these provincial Crowns had over other public foundations. This was the same federal budget that established a new federal Crown foundation-the CFI-with an investment of \$3.15 billion to 2002. The subsequent 1998 budget established the Millennium Scholarship Foundation-with an investment of $\$ 2.5$ billion. Both have enabled the federal government to pursue its research and innovation agendas, and economic development through PSE funding (Aucoin 2003, 2).

Bromley had anticipated that there might be increased scrutiny by the CRA on these new foundations. In his 1993 article on this policy process in British Columbia, Bromley states, "It is important that Crown foundations be managed responsibly so that the privileges which result from their creation will not be attacked and withdrawn by Revenue Canada" (14). Unfortunately, the window of op- portunity did not last. One of the interviewees stated:

Turns out, unfortunately for us, Paul Martin, a year or two after that changed the federal legislation and tax laws to give everybody the same breaks as a foundation so the thing we'd worked like seven years to create became useless two years later and we'd just begun to run gifts [through the Crown foundation]. (Interview no. 35 August 30,2016 )

The proliferation of Crown foundations favoured hospitals and universities. Because of population densities in Ontario and $\mathrm{BC}$, who were first to establish these university Crowns foundations, it had the effect of building up private donor dollars in those provinces. In addition, because the PSE and healthcare policy domains are so heavily funded by government, such tax incentives allowed for lost tax revenues to be directed by donors, moving decision-making control away from the democratic locus of power, as well as from the federal government to the provincial governments.

Crown foundations gave universities an advantage to solicit wills, bequests, and estates (Minton and Somers 2016). Crown foundations are at "arm's length" from government, and therefore from democratic processes (Aucoin 2003, 2). This gives them more flexibility in terms of advocating for particular positions that may not align with the views of the government. As one interviewee noted, "That's why people set up or give to foundations as opposed to directly to charities - [when at] arm's length [then] we use existing resources, leverage existing resources, enhance existing resources to accomplish this new purpose or broader purpose" (Interview no. 41, April 17, 2016). This individual went on to indicate that the network of donors who advocated for these Crown foundations was well connected to local community in a way that (they believed) fostered better direction of major gifts than governments.

Federally, it took about a decade to evaluate and reconsider the policy advantage provided to private donors through the proliferation of provincial university Crown foundations. In 1996/97, the policy entrepreneurs for the Crown foundation policy agenda were surprised that the tax advantage for these organizations was suppressed in the federal budget. In spite of assurances Bromley had received in 1988, the federal Department of Finance made significant changes to the fundraising landscape in the Income Tax Act (1985) in 1996/97, eliminating the 
advantage that would have otherwise continued to have been bestowed on hospitals and universities across the provinces. The budget indicated that the policy would:

...adopt a common limit of $75 \%$ of net income for donations to all charities by individuals and corporations for the 1997 and subsequent taxation years - raising the limit for most charities from $50 \%$, and lowering the limit for donations to the Crown and Crown foundations from $100 \%$. With this proposal, all charities would be able to attract donations on a level playing field.... For donations to charities other than the Crown, these proposals would result in the limit being raised from $20 \%$... to $75 \%$. (Canada 1997,112 )

In the same budget, the Liberal government established a new federal Crown foundation, the Canadian Foundation for Innovation (CFI), with an investment of $\$ 3.15$ billion to 2002. In the 1998 budget, the Millennium Scholarship Foundation was established with an endowment of $\$ 2.5$ billion (Aucoin, 2003). The government of Canada eliminated the advantage provided to Crown foundations by lowering the previous lifetime limit from $100 \%$ to $75 \%$. Thereafter, all registered charities, including Crowns, qualified for tax benefits for donating up to $75 \%$ of annual earned income.

There were no official statements from the federal government regarding the rationale for the above-noted changes. Anecdotally, in referring back to the federal government's 1996/97 budget, the establishment of Crown foundations for universities both contradicted and complied with the Ministry of Finance's policy directives on charitable tax structures. One stated expectation of the fiscal policy toward donations of that budget was that donation incentives should increase contributions to Canadian charities but in an equitable way across both organizational types and across policy domains (e.g. health vs. education vs. poverty relief).

According to interviews conducted for this research (e.g. Interview no. 41, 2017, April 17; Interview no. 17, 2014, November 17), policy transfer across the provinces led to a "tremendous influx of activity and dollars generated within the sector across the country" (Interview no. 17, 2014, November 17). However, the progress toward implementation was protracted by provincial politics which stymied the policy entrepreneurs' ability to take advantage of the tax incentive unique to Crown foundations. This limited the potential for exponential philanthropic revenue growth. For example, in 1991, the Saskatchewan Progressive Conservative government under Premier Grant Devine was defeated by Roy Romanow's NDP. According to one interview:

It took six or seven years to actually get it [a Crown foundation] done because it took an act of the Legislature... It turned into a giant mess because I had it $90 \%$ of the way through the Conservative government and all my connections there, and then Devine lost the election and the NDP took over. Everything that was in the works that related to the previous government was basically trashed... it took two or three years to convince the NDP that it wasn't some kind of capitalist "whatever." (Interview no. 41, 2017, April 17)

This points to the importance of the political decision-makers in moving forward policy agendas related to foundations. It is also documented that the BC case took at least three or four years from idea to implementation (Bromley, 1997). A review of the timing of these changes provides an indication of the relation between election cycles and policy innovations for foundations. The protracted timelines in Québec (see table 1), Saskatchewan and $\mathrm{BC}$ are indications of just how much commitment is required to push such a policy idea to implementation.

In addition to convincing the provincial governments of the value these new foundations could bring, in hindsight, the policy advocates might also have paid heed to the federal view on the proliferation of provincial Crown foundations for universities. The federal government would have been seeing a significant delegation of spending power in the PSE sector: from the federal government to the provinces, and from the provinces and universities, and from universities to private donors. This is important because "provincial governments continue to be the largest source of government revenue for non-profits by a wide margin, due to their jurisdictional responsibility for health, social welfare, and education" (Elson, 2016, p. 16). Establishing the correlation between legislation and this "influx of dollars" (Interview no. 17, 2014, November 17) and the timelines from idea to implementation across the other seven provinces requires further research and is beyond the scope of this article.

While the PSE sector benefitted from this tax incentive for a short while (1987-1997), the policy environment for foundations changed in Canada. The idea of Crown foundations for universities was a potential solution to a 
systemic policy "problem" - resource scarcity. Resource scarcity in the third sector was compounded by the fact that, in the 1996/97 federal budget, the government was also "delegating" public services, creating increased demand for philanthropic dollars, i.e., alternative revenue sources for charities. Crown foundations were nonetheless provincial entities that created tax expenditures at the federal level, but they left decision authority and influence in the hands of foundation donors and directors at the provincial level (Howard, 1999; Laforest, 2009; Philipps, 2003).

\section{Discussion}

The development of philanthropic policy networks was in its infancy when Crown foundations were being established across the provinces. Conversations between colleagues turned into conferences, conferences turned into articles, articles turned into books, and informal networks and connections turned into professional umbrella organizations. This policy transfer sparked the CAGP and the CASE chapter for western Canada. The CAGP was started in 1993 and held their first annual conference in 1994. Neely (1995) and Bromley (1993) wrote articles and made conference presentations about the Crown foundation opportunity. Somers and Minton brought together the learnings from a number of such occasions, along with their research and Minton's US experience into the first edition of the Planned Giving for Canadians (Minton \& Somers, 2016).

These efforts quickly moved from a focus on tax planning to a broader focus on the professionalization and development of individuals working in the foundation and philanthropic sectors. For the first time, there was an umbrella organization representing more than a single related profession in the CAGP. However, the legitimacy of the foundation sector, and apprehensions about their driving motive prompted blowback from the federal government. These findings are consistent with observations about the role of the government vis-à-vis the third sector in Canada:

Critics have also observed that the charitable tax credit transfers decision-making power over what services are funded from elected governments to individual philanthropists, and especially to a small group of very wealthy donors. Besides raising concerns about democratic control of public services, this system is likely to result in disparate levels of funding to different services depending, not on the needs of citizens, but on the preferences and wealth of those who make charitable gifts. (Philipps, 2003, p. 916)

The rollback to $75 \%$ and equalization to all charities for the lifetime giving tax incentives effectively put the decision power for spending in these fields back at the federal level. In spite of the setback for the Crown foundation opportunity, the collaborative efforts persisted.

The policy entrepreneurship in this case was closely connected to the expansion of the third sector in Canada in the early 1990s. Evidence is lacking, however, with respect to the actual policy outcomes or outputs that result from the creation of Crown foundations for universities across nine provinces. Anecdotally, and according to the interviews conducted for this research, the combination of the capital gains tax exemption for donations of publicly listed securities, along with the proliferation of Crown foundations for universities, led to an inequitable distribution of donations geographically and by charitable cause. Hospitals have been registered as charities in Canada since 1973. There were 263 registered hospital foundations in 2016.

Relations between the third sector and the state had previously been loosely coupled and multilateral. In this case, evidence of these relations now becoming increasingly formalized, hierarchical, and unilateral is presented. Previous research has pointed to the closed nature of policy processes in the federal Department of Finance (Elson, 2011; Interview no. 18, 2015, June 6; Interview no. 19, 2015, June 6; Interview no. 22, 2015, May 14; Interview no. 25, 2016, March 6; Interview no. 26, 2014, Nov 21; McRae, 2011). These were reaffirmed in the research conducted for this case study and through the interviews with policy participants in this case. This reflects the ongoing assumptions about state-third sector subordinate relationships that have underpinned developments in the sector since the Carter Commission (1969).

\section{Conclusion}

In this case, Crown foundations were an instrument of policy entrepreneurship coming from the third sector. The objective of the proliferation of these foundations was to increase resources available to universities. This policy entrepreneurship that was mobilized around a tax incentive for foundations further precipitated organizational networking across the country. Informal personal and 
professional networks created channels to share information about this potential tax incentive for universities. In short order, those networks became formal umbrella organizations: the Canadian Association of Gift Planners (CAGP) and the Canadian Council for the Advancement and Support of Education (CASE).

The policy entrepreneurs were effective in this case at setting the policy agenda and transferring it from province to province in a relatively short period of time. In addition to the provincial university Crown foundations, 19 of the 26 (currently registered) PSE foundations were established between 1981 and 2005. While the policy community was focused on a single tax incentive the federal government changed the playing field. This is illustrated by the immediate establishment of the Millennium Scholarship Foundation in 1998.

As of 2019, there are no Crown foundations registered with the CRA for Canada's provincial universities. Several parallel foundations exist at some of the following organizations, for example: University of Victoria (first registered PSE foundation in 1967); Royal University Hospital in Saskatoon (1983); Mount Royal University (1991); Vancouver Island University (1994); York University (2002); and, the University of Winnipeg (2002). In total, there are 35 registered foundations associated with universities in Canada, six of which are noted above (Canada, 2019). The idea of establishing Crown foundations for provincial universities in order to access the incentive for the Crown was novel, although short-lived. The window of opportunity really only lasted for seven years, from 1987-1994. In 1997, the federal government levelled the playing field by enacting the $75 \%$-of-lifetime-earnings rule.

The establishment of the university Crown foundations from 1987 until 1998 is an example of the opportunities and constraints facing third sector policy entrepreneurs' and foundations' policy engagement in Canadian public policy. It illustrates potential limitations to the influence of foundations for social policy, and PSE policy especially. The policy transfer was driven at the provincial level and by third sector policy entrepreneurs, right up until the 1997 federal budget. At that point, the federal government's policy agenda superseded these efforts. The provinces could incorporate as many Crown foundations as they liked, but the federal Department of Finance could also eliminate the advantage of doing so with the stroke of a pen by amending the Income Tax Act (1985). It did just that in 1997 with extension of the $75 \%$ maximum lifetime contributions to all charities, not just the Crown, and lowered the $100 \%$ advantage of donating to the Crown down to $75 \%$ (while in that same federal budget establishing a new federal Crown foundation).

\section{References}

Abelson, D. (2005). Any ideas? Think tanks and policy analysis in Canada, in L. Dobuzinskis, M. Howlett, \& D. Laycock. Policy analysis in Canada: State of the Art. Toronto: University of Toronto Press, 791-823.

Abelson, D.E. (2016). Northern lights: Exploring Canada's think tank landscape. McGill-Queen's Press-MQUP.

Act Respecting University Foundations, 1996 RSQ, CQLR c F-3.2.0.1. Available at: https://www.canlii. org/en/qc/laws/stat/cqlr-c-f-3.2.0.1/13328/cqlr-c-f3.2.0.1.html (accessed October 6, 2019).

Anheier, H. K., \& Daly, S. (2006). Roles of foundations in Europe: A comparison. In K. Prewitt, M. Dogan, S. Heydemann, and S. Toepler (Eds.) The legitimacy of philanthropic foundations: United States and European perspectives. New York: Russell Sage Foundation, 192-215.

Aucoin, P. (2003). Independent foundations, public money and public accountability: Whither ministerial responsibility and governance? Canadian Public Administration, 46(1), 1-26.

Blumberg, M. and Sawyer, M. (2018). Blumberg's Snapshot of the Canadian Charity Sector 2016. Available at: https://www.globalphilanthropy.ca/images/uploads/Blumbergs Canadian Charity Sector Snapshot 2016.pdf retrieved October 6, 2019.

Bowman, T. (1996). Crown foundation at the $U$ of $S$ can mean substantial tax savings for donors. On Campus News. Saskatoon: University of Saskatchewan.

Bromley, B. (1993). Parallel foundations and crown foundations. The Philanthropist, 11(4), 37-52.

Bromley, B. (1997). Dolphins, tuna and mudsharks: Reflections on the Bre-X budget for charities. The Philanthropist, 14(1), 27-41.

Bromley, B. (1999). Answering the broadbent question: The case for a common law definition of charity. Estates Trust and Pensions Journal, 19(21). 
Burrows, M. (Sept. 15, 2009). Unlocking more wealth: How to improve federal tax policy for Canadian charities. The Charity Papers. C.D. Howe Institute: e-brief.

Canada, Income Tax Act, RSC 1985.

Canada Revenue Agency (2016). What is the difference between a registered charity and a non-profit organization? Accessed Aug. 14, 2017 https://www.canada.ca/en/revenue-agency/services/charities-giving/ giving-charity-information-donors/about-registered-charities/what-difference-between-a-registered-charity-a-non-profit-organization.html.

Canada Revenue Agency (1997). Budget plan, Building the Future for Canadians: Budget 1997. February 18. Ottawa: Department of Finance. Retrieved from https://fin.gc.ca/budget97/binb/bp/bp97e.pdf.

Canada Revenue Agency (1997b). Report of the Chief Electoral Officer of Canada on the 36th General Election. Ottawa: Elections Canada. Accessed August 14, 2017. Retrieved from http://www.elections. ca/res/rep/off/ceo/ceoreport e.pdf.

Canada Revenue Agency (2019). Charities and Giving. List of Charities. Accessed October 14, 2019. Retrieved from https://apps.cra-arc.gc.ca/ebci/hacc/ srch/pub/bscSrch?q.srchNm=university+foundationधq.stts=0007\&p=1.

Crown Foundations Act, SS 1994, c C-50.12. Available at https://www.canlii.org/en/sk/laws/astat/ss-1994c-c-50.12/latest/ss-1994-c-c-50.12.html?resultIndex $=1$ (accessed October 6, 2019).

Elson, P. (2011). The Emergence of structured subnational voluntary sector-government relationships in Canada: a historical institutional analysis. Voluntary Sector Review, 2(2), 135-155.

Elson, P. (Ed.) (2016). Funding policies and the nonprofit sector in Western Canada: Evolving relationships in a changing environment. Toronto: University of Toronto Press.

Fleishman, J. (2007). The Foundation: A great American secret; how private wealth is changing the world. Public Affairs. New York.

Hall, R. H., \& Quinn, R. E. (1984). Organizational theory and public policy. Beverly Hills: Sage.

Higher Education Foundation Act, SNB 1992, c H-4.1. Available at: http://canlii.ca/t/jtc4 (accessed October 19, 2019).

Hoffstein, M. E. (November 25-27, 2007). Private foundations and community foundations. Canadian Tax Foundation Fifty-Ninth Annual Tax Conference. An Act to Amend the Income Tax Act (Revocation of Registration), C-47, Second Session, Fortieth Parliament, 57-58 Cong.

Howard, C. (1999). The Hidden welfare state: Tax expenditures and social policy in the United States. Princeton University Press.

Howlett, M. (1997). Issue-attention and punctuated equilibria models reconsidered: An empirical examination of the dynamics of agenda-setting in Canada. Canadian Journal of Political Science/Revue canadienne de science politique, 30(1), 3-29.

Howlett, M. (1998). Predictable and unpredictable policy windows: Institutional and exogenous correlates of Canadian federal agenda-setting. Canadian Journal of Political Science/Revue canadienne de science politique, 31(3), 495-524.

Imagine Canada and Philanthropic Foundations Canada (2014). Asset and Giving Trends of Canada's Grant-making Foundations. Accessed Mar 5., 2017 http://sectorsource.ca/sites/default/files/resources/files/trends-canadas-grantmaking-foundations-sept2014.pdf.

Kendall, J. (January 2000). The Mainstreaming of the Third Sector into public policy in England in the late 1990s: whys and wherefores. Civil Society Working Paper, 2. Policy \& Politics, 28(4) October 2000, 541-562.

Kingdon, J.W. (1995). Agendas, Alternatives, and Public Policies. NY: Harper Collins, Longman.

Kryvoruchko, I. (2013). Three Essays in public economics: Flat taxes, foundation operations and giving. (unpublished doctoral dissertation). McMaster University, Hamilton, Ontario, Canada.

Laforest, R., ed. (2009). The New Federal Policy Agenda and the Voluntary Sector: On the Cutting Edge. 
Montréal and Kingston: McGill-Queen's University Press.

Lecours, A. (2005). New Institutionalism: Theory and Analysis. Toronto: University of Toronto Press.

Lenkowski, L. (2002). Foundations and Corporate Philanthropy. In The State of Nonprofit America, L. Salamon (Ed.), 355-386. Washington, DC: Brookings Institute.

Lindquist, E. A. (1989). Behind the myth of think tanks: The organization and relevance of Canadian policy institutes. Berkeley: University of California.

Manitoba Foundation Act, CCSM 1993, c. F155. Available at: https://www.canlii.org/en/mb/laws/stat/ ccsm-c-f155/latest/ccsm-c-f155.html?autocompleteStr=manitoba\%20foundation\%20act\&autocompletePos=2 (accessed October 6, 2019).

Memorial University Foundation Act, SNL 1996, c M-7.1, Available at http://canlii.ca/t/jz77 (accessed October 19, 2019).

Minton, F. \& Somers, L. (2016). Planned giving for Canadians: A guide to instituting and managing a successful planned giving campaign. 3rd ed. Cambridge, MA: PC Calc.

Neely, S. P. (1995). Recent developments in crown agency foundations. The Philanthropist, 12(3), $31-51$.

Payne, A. \& Zhao, H. (2007). Uncharitable treatment? Why donations to private and public foundations deserve equal tax status. E-briefs 38, Toronto: C.D. Howe Institute.

Pearson, H. (2010). Funder collaboratives: trend or tool. The Philanthropist, 23(2), 120-125.

Philanthropic Foundations Canada (PFC). 2017. Canadian Foundation Facts: 2016. Accessed Sept. 8, 2017, online at: http://pfc.ca/canadian-foundation-facts.

Philipps, L. (2003). Thinking critically about the taxation of capital gains on donated public securities (or looking paragraph 38[a.1] in the mouth). Canadian Tax Journal 51(2), 913.

Phillips, J., B. Chapman, \& D. Stevens (2001). Between state and market: Essays on charities law and policy in Canada. Montréal and Kingston: McGill-Queen's University Press.

Phillips, S. D. (2007). Policy analysis and the voluntary sector: Evolving policy styles. In L. Dobuzinskis, M. Howlett, \& D. Laycock, Policy Analysis in Canada: State of the Art, New York: Palgrave, 497. Phillips, S. D. \& Rathgeb Smith, S. (Eds.) (2011). Abingdon, UK: Routledge.

Powell, W. W., \& DiMaggio, P. J., eds. (1991). The New Institutionalism in Organizational Analysis. Chicago: University of Chicago Press.

Prewitt, K. (2006). Foundations. In W. W. Powell and R. Steinberg (Eds.), The Nonprofit Sector: A Research Handbook. New Haven, CT: Yale University Press, 355-377.

Prewitt, K., Dogan, M., Heydemann, S. \& Toepler, S. (2006). The Legitimacy of philanthropic foundations: United States and European perspectives. New York, NY: Russel Sage Foundation.

Reckhow, S. (2016). More than patrons: How foundations fuel policy change and backlash. PS: Political Science \& Politics, 49(03), 449-454.

Reich, R. (2016). Repugnant to the whole idea of democracy? On the role of foundations in democratic societies. PS: Political Science \& Politics, 49(03), 466-472.

Sexty, R. W., (1980). Autonomy strategies of government owned business corporations in Canada. Strategic Management Journal, 1(4), 371-384.

Sharpe, D. (1994). A portrait of Canada's charities: The size, scope and financing of registered charities. Toronto, ON: Canadian Centre for Philanthropy.

Stone, D. A. (1997). Policy paradox: The art of political decision making. New York: W. W. Norton.

Stone, D., Denham, A. \& Garnett, M., eds. (1998). Think tanks across nations: A comparative approach. New York: Manchester University Press.

Teles, S. M. (July 2016). Foundations, organizational maintenance and partisan asymmetry. PS: Political Science and Politics 49(3): 455-460. 
Universities Foundations Act, SA 1991, c U-6.5. Available at https://www.canlii.org/en/ab/laws/astat/sa1991-c-u-6.5/latest/sa-1991-c-u-6.5.html (accessed October 6, 2019).

University Foundations Act, SBC 1987 c 50. Available at: http://www.bclaws.ca/civix/document/id/94consol18/94consol18/87050 (accessed October 6, 2019).

University Foundations Act, SC 1991. Available at: https://nslegislature.ca/sites/default/files/legc/statutes/univfoun.htm (accessed October 6, 2019).

University Foundations Act, SO 1992, c 22. Available at: https://www.canlii.org/en/on/laws/stat/so-1992-c-22/ latest/so-1992-c-22.html? resultIndex=2 (accessed October 6, 2019).

University of Saskatchewan (1994). Establishment of a crown foundation for the U of S. Saskatoon, SK: U of $S$ Board of Governors.

\section{Contact Information}

Jacqueline Thomarat

jacquie.thomarat@usask.ca

\section{Notes}

1 "Top grantmaking foundations were identified using a combination of T3010 financial data and criteria derived from Grant Connect for each year from 2002 through 2012. T3010 data was obtained from Canada Revenue Agency (CRA) in the form of an electronic database. To be evaluated, organizations had to meet a number of scope criteria: 1 . to be designated by CRA as either a public foundation or a private foundation; 2 . to have not had their charitable status revoked for cause; and 3 . to have received more than $50 \%$ of their revenues from non-governmental sources." Out of scope of this survey data were "Operating charity - Charitable status revoked for cause; More [sic] than $50 \%$ revenues from government sources; Less [sic] than $\$ 50,000$ in gifts to qualified donees on line 5050" (Imagine Canada and PFC 2014, 18). This means that Crown foundations and parallel foundations (such as hospital founda- tions or university foundations) were beyond the scope of the available data.

2 Colleges in BC, as in other provinces, including Saskatchewan, were already agents of the Crown and therefore were not contemplated in the draft legislation (Bromley, 1993; Interview no. 41, 2017, April 17). 